\title{
Siborg Teknolojisi ve Uygulamalarının Tıp Etiği Açısından Değerlendirilmesi ${ }^{*}$
}

\author{
Filiz BULUT, Gülten ÖZKAN
}

Bursa Uludağ Üniversitesi Sağlık Bilimleri Enstitüsü, Tıp Tarihi ve Etik Anabilim Dalı, Bursa.

\section{ÖZET}

Sağlık hizmetlerinde kullanılan tıbbi teknolojinin olanakları giderek genișlemektedir. Tıbbi teknolojinin hızlı gelișimi sayesinde günümüz tıbbında, insan vücudunun hemen her yerini değiştirme ve geliştirme olanağından sıkça söz edilir olmuştur. Protez uzuvlardan beyin içine implante edilen protezlere, kalp pillerinden kusma yetisine sahip plastik mideye, koklear implantlardan giyenin ne yapmak istediğini anlayabilen biyonik kol ve bacaklara uzanan birçok gelişme bulunmaktadır. Günümüz tıbbındaki bu gelişim çağının en önemli örneğini Siborg teknolojisi oluşturmaktadır. Kişisel duyularını, yeteneklerini geliştirmek amacıyla insan vücuduna kalıcı olarak yerleștirilmiş veya kalııı olarak tutturulmuș elektronik bir cihaza sahip insan biçiminde tanımlanan Siborg, birçok tartışmayı da beraberinde getirmiștir. Bu teknolojinin en büyük riski olarak gelişmiş motor ve hesaplama yeteneklerine sahip bir sınıfı ortaya çıkarması ve bu sınıfa ait kişilerin yeteneklerinin genel popülasyonun ötesine geçmesi gibi etik ve hukuki boyutları açısından kaygı verici sorun alanları bulunmaktadır. Bu sorunları Tıp Etiği açısından değerlendiren bu çalışmada, Siborg teknolojisinin tıpta kendini tedavi edici bir hizmet alanı olarak sunduğu saptaması yapılmıştır. $\mathrm{Bu}$ durum sağlık hizmetlerinin boyutlarının dönüşümüne işaret etmektedir. Bununla birlikte bir tedavi edici hizmet alanı olarak Siborg uygulamalarının modern tıbbın içinde yer alması Tıp Etiği açısından da daha kabul edilebilir görünmektedir. Bu saptamadan hareketle Siborg uygulamalarının sağlık hizmetlerinin dönüşümüne olası etkileri tartışılmaya açılmakta ve Siborg uygulamalarına yaklaşımın nasıl olması gerektiği Tıp Etiği açısından değerlendirilmektedir.

Anahtar Kelimeler: Siborg. Sağık gereksinimi. Sağık hizmeti. Tıp etiği. İleri teknoloji.

Evaluation of Siborg Technology and Practices in terms of Medical Ethics

\begin{abstract}
The opportunities of medical technology used in health services are gradually expanding. Thanks to the rapid development of medical technology, the opportunity of changing and developing almost every part of the human body has been frequently mentioned in today's medicine. There are many improvements from prosthetic limbs to the implants implanted into the brain, from the pacemarkers to the plastic stomach with vomiting, and from the cochlear implants to the bionic arms and legs that can understand what the wearer wants to do. Cyborg technologies constitute the most important instance of this era of development in today's medicine. Cyborg, defined as a human with an electronic device permanently put or attached to the human body in order to improve his personal senses and abilities has caused many discussions. As the biggest risks of this technology, there are areas of concern for its ethical and legal dimensions, such as creating a class with advanced engine and computing abilities and the abilities of individuals belonging to this class that go beyond the general population. In this study that evaluates these issues in terms of Medical Ethics, it has been determined that Cyborg technology offers itself as a therapeutic service area in medicine. This points to the transformation of the dimensions of health services. Nevertheless, in terms of Medical Ethics it seems more acceptable that as a therapeutic service area Cyborgs take place in modern medicine. Based on this determination, the possible effects of Cyborg technologies on the transformation of health cares are opened for discussion and how the approach to Cyborg technologies should be is evaluated in terms of Medical Ethics.
\end{abstract}

Key Words: Cyborg. Health requirement. Health care. Medical Ethics. Advanced technology.

Geliş Tarihi: 22.Nisan.2020

Kabul Tarihi: 25.Ağustos.2020

* X. Türkiye Biyoetik Sempozyumu 'Sağlıkta İleri Teknoloji ve Etik' (17-18 Ekim 2019, İstanbul) konulu sempozyumda "Sağlık Hizmetlerinin Yeni Boyutu: Tedavi Edici Sağlık Hizmetlerinden Geliştirici Hizmetlere Dönüşümün İzleri" başlığında sözlü bildiri olarak sunulmuştur.

Filiz BULUT, MSc.

Bursa Uludağ Üniversitesi Sağlık Bilimleri Enstitüsü,

Tıp Tarihi ve Etik Anabilim Dalı, Bursa.

Tel: 02242954160

E-posta: filizbulut.2816@gmail.com

Yazarların ORCID ID Bilgisi:

Filiz BULUT: 0000-0002-3674-8294

Gülten ÖZKAN: 0000-0002-1679-0380
İnsanlık var olduğu tarihten bu yana birtakım ihtiyaçlarını karşılayacak ve hayatını kolaylaştıracak araçların yapımı için bilgiye, yeteneğe ve deneyime gereksinim duymuştur (Dülger, 2018). Varoluştan teknoloji çağına uzanan süreçte insanın sahip olduğu özellikler, kendini hemen her alanda göstermiş, özellikle tıbbi teknolojinin gelişiminde ve kullanım alanında oldukça etkili olmuştur.

İnsanın ve ürettiği teknolojinin bu gelişim evresini bir geçiş çağı olarak yorumlamak mümkündür. Bu ilerleme toplumun bir bütün olarak teknolojiyle simbiyoz bir ilişki oluşturmasına neden olurken bireylerin artık teknoloji ile birleşmeye başladığı bir etkileşimi ifade 


\section{F. Bulut ve G. Özkan}

etmektedir (Park, 2014). İnsan yaşamını, makineler olmadan daha 'insancıl' bir biçimde sürdürmekteyken, günümüzde teknolojik gelişmeleri sayesinde günlük yaşantı, birtakım cihazlara bağımlı halde sürdürülmektedir. Bu bağımlılık daha kolay ve daha rahat bir yaşam arayışı için devam ederken, insan-makine kavramları arasındaki çizgi de giderek belirsizleşmektedir.

$\mathrm{Bu}$ durumun ilk olarak transplantasyon tıbbının ortaya çıkışı ile başladığı ileri sürülebilir. 1954 yılında gerçekleşen ilk böbrek nakli ve Türkiye'de 1967 yılındaki ilk kalp nakli operasyonlarından bu yana akciğer, karaciğer, pankreas gibi organların yanı sıra el, kol, yüz nakli gibi insan vücudunun diğer parçalarının da transplantasyonunun gerçekleştirilmesi mümkün hale gelmiştir. Bugün gelinen noktada, vücudun kendi organizmasına ait organların yanında insan vücuduna giderek daha fazla yapay organlar yerleştirilmektedir. Yapay kalp kapakçıkları, kalp pilleri, arteryel stentler, deri altı ilaç pompaları ve yapay uzuvlar kolaylıkla yerleştirilebilmektedir. Özellikle yapay uzuvlar, vücuda tutturulmuş protezler eski moda ahşap bir bacağın aksine daha da geliştirilmekte ve vücuttan çıkarılması daha zor hale getirilmektedir (Schermer, 2009). Bu durum bedenin bir makine olarak algılanması ve vücudun yapay parçalarla birleştirilmesinin mümkün hale geldiği gerçeğini kabul etmek olarak yorumlanmaktadır (Schermer, 2009). Protez uzuvlardan beyin içine implante edilen protezlere, kalp pillerinden retinal protezlere, kök hücrelerden yapılan kusma yetisine sahip plastik mideye, işitme testini geçebilecek düzeyde geliștirilen koklear implantlara, giyenin ne yapmak istediğini anlayabilen biyonik bacaklara uzanan birçok gelişme bir transhuman çağı içinde olduğumuza işaret etmektedir.

Bedenlerin klonlanması, hibernasyon, insan-varlığın geliştirilmesi, CRISPR teknolojisi gibi hali hazırda etik tartışma konularını oluşturan bu başlıklara yeni bir etik sorun alanı olarak Siborg teknolojisinin boyutlarını eklemek mümkündür. Siborg (Cyborg), insan vücudunu daha nitelikli ve biyolojik olarak daha üstün hale getirmeyi hedefleyen yarı robot insanı ifade etmektedir (van Hooijdonk, 2017).

\section{Siborg Nedir?}

Sözlük anlamı incelendiğinde, Yunanca 'kybernetes' in karşılığ 1 olarak sibernetik organizma biçiminde tanımlanmakta ve dümencilik, dümeni idare eden kişi anlamlarını taşımaktadır (Nişanyan Sözlük). Sibernetik organizmadan türetilen 'Siborg' teriminin ilk olarak 1960 yılında ortaya atıldığı bildirilmektedir. Savunmasız durumdaki insan vücudunun uzay yolculuğu ve keşif gereksinimlerinin teknolojik olarak nasıl karşılanacağı sorunu üzerine bu tanım Amerikalı araştırmacilar Manfred Cylnes ve Nathan Kline tarafindan ortaya atılmıştır (Schermer, 2009). Bir diğer tanım, Siborg'u bir metafor olarak kullanan Donna
Haraway'a aittir. Haraway, bir Siborg Manifestosu yayınlayarak Siborg'u, makine ile organizmanın oluşturduğu melez, kurgusal, toplumsal gerçekliğe ait bir yaratık olarak tanımlamıştır (Haraway, 2006). Günümüzde yaygın olarak kullanılan ve bilinen tanımı ise, kişisel duyularını, yeteneklerini geliştirmek amacıyla insan vücuduna kalıcı olarak yerleştirilmiş veya kalıcı olarak tutturulmuş elektronik bir cihaza sahip insan biçimindedir (Park, 2014).

Siborg tanımının ortaya çıkmasından çok sonra resmi olarak kabul edilen dünyanın ilk siborgu Neil Harbisson'dur (The Guardian, 2014). Kafasına yerleştirilen Eyeborg isimli bir cihazla, sesli titreşimler yoluyla beyninde renkleri algılaması sağlanmıştır. Bununla birlikte internet bağlantısı ve bluetooth özelliği sayesinde herhangi bir cihaza ya da internete bağlanabildiğini belirtmektedir. Kendini yüzde yüz insan olarak hissetmediğini bildiren Harbisson 2010 yilında Moon Ribas ile insanların Siborg olmasına yardım etmek ve Siborg olmayı teşvik etme amacı taşıyan uluslararası bir organizasyon olan Siborg Vakfi'nı kurmuştur (CYBORG ARTS, 2020). Harbisson'un yakın arkadaşı olan Moon Ribas da ayaklarında dünyanın herhangi bir yerinde meydana gelen depremleri gerçek zamanlı titreşimlerle algılayan implanlara sahip bir Siborgdur. 2017 yılında ayrica yeni duyu ve yeni organların yaratılmasını destekleyen bir dernek olan Transpecies Society'yi kurmuşlardır (CYBORG ARTS, 2020).

Dünyada ilk örneklerini gördügüümüz bu Siborglar, birçok tartışmayı da beraberinde getirmiştir. Bu teknolojinin en büyük riski olarak gelişmiş motor ve hesaplama yeteneklerine sahip bir sınıfı ortaya çıkarması ve bu sınıfa ait kişilerin yeteneklerinin genel popülasyonun ötesine geçmesi olarak belirtilmektedir (Barfield \& Williams, 2017). Bazı fütüristler tarafından, insan vücudunu askeri veya savaş operasyonlarının dayattığ 1 belirli koşullara uyarlamak için Siborg teknolojisinin yaygın bir şekilde kullanılacağı tahmin edilmiştir (Schermer, 2009).

Siborg teknolojisinin insanlık için ciddi boyutlarda yan etkilerinin olabileceği, etik ve yasal ilkelerin nasıl yorumlanacağı, bir akım haline gelebileceği, insanı insan yapan değerlerin değişikliğine sebep olacağı gibi birtakım kayg1 verici değerlendirmeler yapılmaktadır (Barfield \& Williams, 2017; Gillett, 2006; Hansson, 2005; Miles, Siegler, Schiedermayer, Lantos \& La Puma, 1988; Park, 2014; Reinares-Lara, OlartePascual \& Pelegrín-Borondo, 2018; Schermer, 2009; Warwick, 2003). Bu riskler göz önüne alındığında günümüz modern tıbbının kabul ettiği ve sağlık hizmetlerinin içerisinde yer verdiği bu türden uygulamaların yapılıyor olması, temel olarak günümüzdeki sağlık hizmetlerinin amacını sorgulatmaktadır. Siborg teknolojisinin genel olarak tıbbın amaçlarına ve hastanın tedavisine hizmet etmesinin yanı sira Miles ve arkadaşlarının 1988 yılında belirtmiş olduğu 'sağlıklı 


\section{Siborg ve Tıp Etiği}

bir insanın fiziksel gücünü veya hafızasını kendi doğal yapısının üzerine yükselten bu teknolojiye yaklaşımın nasıl olması gerektiği' önemli bir etik sorusu olarak karşımıza çıkmaktadır (Miles et al., 1988). Bu soru günümüzde ne tür bir insan olmak gerektiği bakımından ilgisinin kurulması açısından da önemli görünmektedir. Bu açıdan sağlık hizmetlerinde giderek bir akım haline gelen bu kavramın günümüz sağlık hizmetlerinin tedavi edici ve esenlendirici boyutlarını nasıl etkilediği ve sağlık hizmetlerinin içeriğini ne derece dönüştürdüğü tartışılması gereken önemli bir sorun alanı olarak karşımıza çıkarmaktadır. Tıbbi teknolojinin sınırlarının bu denli genişlemesi ile Siborg teknolojisinin, kaynakların adil dağılımından sağlıkta eşitsizliklerin artmasına, insan vücudunun değişen tanımlarından sağlık gereksinimlerinin değişmeye başladığına ve buna bağlı olarak yeni bir sağlık hizmeti altyapısını ortaya çıkarmak gibi bir potansiyele sahip olduğuna ilişkin sorun alanları oluşturmaktadır. Bu kapsamda Siborgun sağlık hizmetlerindeki yerini Tıp Etiği açısından sorgulamak önemli bir girişim olarak görünmektedir. Bu bağlamda çalışmanın amacı, insanı geliştirmeye yönelik ileri teknoloji uygulamalarının kabul edilebilir görünen yüzü olarak betimleyebileceğimiz Siborg teknolojisinin, sağlık hizmetlerinin dönüşümüne olası etkilerini tartışmaya açmak ve Siborg teknolojine yaklaşımın nasıl olması gerektiğini tıp etiği açısından değerlendirmektir.

$\mathrm{Bu}$ amaçla John Harris'in 'sağlık gereksinimi' tanımı ile Wright ve arkadaşlarının önerdiği 'sağlık gereksinim değerlendirmesi' bir ölçüt olarak alınarak değerlendirme yapılmaya çalışılmıştır (Harris, 2004; Wright, Williams \& Wilkinson, 1998).

\section{Tıp Etiği Açısından Siborg}

\section{Geleceğin Sağlık Hizmetlerine Olası Etkileri}

İnsan vücuduna implante edilen Siborg cihazlarının birincil özelliği, gelişmiş motor ve hesaplama yetenekleri kazandirmasidir. Bu nedenle sadece uzuv kayıplarında bir tedavi yöntemi olarak değil, daha üstün bir insan yaratma potansiyeli taşımaktadır. Siborg teknolojisinin başta gelen bu özelliği nedeniyle şimdiden hukuk ve politika açısından önemli sorunlar yarattığı belirtilmektedir (Barfield \& Williams, 2017). Sağlıklı insanların da Siborg teknolojisine yönelmesi ve tıptan bunu talep etmeye başlaması, sağlık hizmetlerinin gelecekte nasıl şekilleneceğini düşündürmektedir. Tıbbi teknolojinin gelecekte ölüme dahi tedavi edilebilir bir hastalık olarak yaklaşabilmesi eleştirel bir örnek olarak verilmektedir (Leonhard, 2018). Teknolojinin hızı dikkate alındığında, Siborg teknolojisinin sağlık hizmetlerinin temel özelliklerini nasıl ve ne şekilde etkileyeceğini, ne gibi etik sorunlar yaratacağını sorgulamak gerekir.
Siborg teknolojisinin görünmeyen ve dile getirilmeyen yanı, kendisini bir sağlık gereksinimi olarak sunması ve bu bağlamda sağlık hizmetlerine yön vermesidir. İnsanlık tarihi boyunca tıbbın amacı, insanın iyilik hali üzerine kurulu olması ve insanın bir anlamda mutluluğunu sağlamasıdır. Yaşanan teknolojik gelişmelerle koruyucu, tedavi edici ve rehabilite edici etkinlikleri ile bütüncül bir bakış açısının kazanıldığı bir gelişim yaşanmıştır. Bu süreçte teknolojinin ve tıbbi teknolojinin bir araç olarak tıpta kullanılması söz konusu olmuştur. Bu durum Siborg teknolojisinin geldiği noktada, teknolojinin insan vücudunda parçalara bölünerek, insanı dönüştürmeye ve insanı varlıktan uzaklaştırmaya yarayan bir hizmete dönüşmektedir (Leonhard, 2018). Genel olarak teknolojinin bir amaç olarak insanın hayatında varlık kazandığını bildiren bu saptama haksız sayılmamakla birlikte, çağa ayak uydurmak adına makineleşmenin Siborg teknolojisi ile 1lımlı bir biçimde hayatımıza girdiğini vurgulamak gerekir. Teknoloji şirketlerinin modern tıbbın içine bu denli müdahil olması, sağlık hizmetlerinde göz kamaştırıcı bir etki yaratmış ve tıbbi teknolojinin bu göz kamaştırıcı etkisi karşısında nasıl bir taraf olmak gerektiğini neredeyse sorgulamaya dahi izin vermemiştir. İnsanın vücudunu makineleştiren, hafiza için çipler takabilen, daha üstün bir insan yaratan bu teknoloji karşısında insanlık kendinden uzaklaşmakta, başka bir türe bürünmektedir. Bununla birlikte sağlıkta eşitsizlikler artmaktadır. Sağlık hizmetlerinde kaynakların dağılımında yaşanan sorunlar, Siborg teknolojisinde farklı bir boyut kazanmaktadır. Örneğin 1980'lerde mekanik kalp araştırmalarının durdurulması gerektiği çünkü dağıtım maliyetinin çok yüksek olacağı iddia edilmiştir. $\mathrm{Bu}$ durumun tedavi edici kullanımlarda sosyal eşitsizlikleri azaltabilirken, kapasite artırmaya yönelik implantlar için ödeme yapabilenler olduğunda ise tam tersi bir etki yaratacağı belirtilmektedir (Miles et al., 1988). Tüm insanlık adına kendini var eden tıbbın, belli bir kesime hizmet vererek sağlıkta eşitsizliğe dayalı mekanik bir yapıya dönüşmekte olduğunu göstermektedir.

Günümüz modern tıbbını çeşitli açılardan eleştirmek mümkündür. Ancak en önemli eleştiri tıbbın hasta merkezli yaklaşımdan uzaklaşarak hastalık merkezli bir yaklaşım benimsemesiyle insancıl özünü yitirdiği yönündeki temel eleştiridir (Bulut \& Civaner, 2016). $\mathrm{Bu}$ eleştiri Siborg teknolojisi bağlamında ele alındığında, makine merkezli bir mühendislik hizmetine dönüşen ve böylece bireyleri kendi insani denetimlerinden yoksun birakan bir kurum haline gelerek, geleneksel hasta hekim ilişkisinin söz konusu olamayacağı bir dönüşüme karşılık geldiği ileri sürülebilir. Bununla birlikte Siborg teknolojisinin tıpta yer alması, insanın makineleşmesinin sıradan bir olgu olarak algılanmasına sebep olarak hayatımıza sessizce girmektedir. $\mathrm{Bu}$ durum, sağlık hizmetlerinin doğasına aykırı olmakla birlikte sağlık hizmetlerinin temelden değişim potansiyelini artırabilir. 


\section{F. Bulut ve G. Özkan}

İnsanın Geliştirilmesine Yönelik İleri Sürülen Argümanlar Açısından Siborg

Tıp etiği açısından Siborg teknolojisini insanın geliştirilmesine karşı ileri sürülen argümanlarla birlikte değerlenmek mümkündür. Bu savların, Siborg teknolojisi için ortaya atılan soruları bir yere kadar yanıtlayabildiği belirtilebilir. İnsanın geliştirilmesine karşı ileri sürülen argümanlar şu şekilde ifade edilmektedir (Miah, 2012):

- İnsan madde anlamına gelir: Eğer bir kişi bir amaca ulaşmak için teknolojik bir kısa yol uygularsa, bu onun değerini baltalayabilir.

- Otantik bir yaşam: Belirli kullanımların, bir kişiyi başkasına dönüştürmesiyle/herhangi bir arabulucu unsur ile yaşanan hayatın daha az anlamlı olması.

- Açık gelecek: Kişinin yaşamdaki beklentilerini makul bir şekilde daraltması.

- Morfolojik özgürlük: Devletin sınırlandırması gereken bir şeyden ziyade birisinin biyolojisini geliştirmenin bir insan hakkı olup olmadığı tartışması.

- Mesleki kaygılar: Bir profesyonelin, insanı geliştiren bir uygulama sırasında etik ilkelere uygunluğuna karar verirken geliştirici tekniğin değerinin belirsizliği.

- Toplumsal kaygılar: İnsanların kullanımını destekleyen bir politika geliştirilmesi ve insanların bunlara uygun bir şekilde erişebileceği bir sosyal sisteme işaret etmesinin gerekliliği.

- Adil olma ve adalet: Nasıl finanse edileceği, adaletin nasıl sağlanacağı hakkındaki sorular.

- Yuck faktör: Doğallığımıza aykırı oluşu.

- Sifır toplam sorunu: Birey için faydalar sağlasa da genel/toplam faydanın ortadan kalkacağı.

- Pratik endişeler: Etkili bir şekilde uygulanmadığ durumlar.

Siborg teknolojisinin insanı geliştirmeye yönelik amacı dikkate alındığında, bu savların her birinin tanımladığ1 sorunlar oldukça anlamlı görünmektedir. Siborg teknolojisinin insanı parça halinde değerlendirmesi, insanı madde olarak tanımladığı ileri sürülebilir. Makine ve organizmanın bütünleşmesi ile kişiyi başka bir insana dönüştürerek hayata daha farklı bir bakış aç1sıyla bakmasına, bu bakış açısının insanın makineleşmesinin yanlış bir şey olmadığı inancı ile otantik bir yaşamı ortadan kaldırılabileceği öne sürülebilir. Yuck faktörün önemli bir sav olarak Siborg teknolojisi için geçerli olduğu açıkça belirtilebilir. İnsanın doğal yapısını ortadan kaldırabilme potansiyeli mevcuttur. Açık gelecek savı açısından değerlendirildiğinde, kişinin yaşamdaki beklentilerini daraltmasından ziyade teknoloji odaklı değiştirdiği belirtilebilir. Toplumsal kayg1lar, adil olma, pratik endişeler gibi savlar da Siborg teknolojisine karşı ileri sürülebilecek savlardır. Morfolojik özgürlük savını ayrıca değerlendirmek gerek- mektedir. Siborg teknoloji uygulamaları, bir insan hakk1 olarak tanımlanabilir mi? Eğer bir insan hakk1 olarak tanımlayabiliyorsak, devletin desteklemesi ve herkesin bu haktan eşit yararlanmasını sağlaması beklenir. Bu gerçekten mümkün müdür? Mümkün olmasının yanı sıra, bir şey ne zaman hak olarak tanımlanabilir sorusunun yanıtlanması gerekmektedir.

Özetle bu savlar, insanın geliştirilmesinin niçin doğru olmayacağının açık ifadeleridir. Siborg teknolojisi açıkça göstermektedir ki, bizi rasyonel düşüncenin başlayıp kendine dönerek sorduğu "İnsan nedir?" sorusunun felsefi temellerine götürmektedir. Bu soru bağlamında aynı derinlikteki "İnsanın amacı nedir?" sorusu da beraberinde düşünülebilir. İnsanın bu sorular ile kendini ve yaşamın amacını aradığı yüzyıllar öncesinden kendini bulduğunu düşündüğünü varsayabileceğimiz 21. yüzyıl insanı için çok daha önemli hale geldiği belirtilebilir. Bugün birçok olanağa sahip insan, teknolojiyi aktif bir biçimde kullanarak hayatını inanılmaz kolaylaştırırken açlık, küresel ısınma, savaş, çevre kirliliği, bulaşıcı hastalık salgınları gibi birçok sorunla da sürekli olarak karşı karşıyadır. Bütün bu süreçte insanı parçalara ayıran, kapasitesini artırarak 'üstün bir insan yaratma' iddiası taşıyan ve bu iddiayı hayata geçirebilen teknoloji karşısında, insan varlığın özünü ve insanın bu dünyadaki varoluş amacını sorgulamak gerekmektedir.

İnsan zihni ve davranışı üzerinde en net etkiye sahip olan nöroprostetik ve Deep Brain Simulation gibi teknolojilerin, insanın sadece karmaşık bir makine olduğuna ve beynin sadece bir bilgisayar olup düşüncelerimizin ve kimliğimizin bir yazılımdan ibaret olduğuna kanıt gibi gösterilebildiği belirtilmektedir (Schermer, 2009). Teknolojinin insanı bir makine olarak değerlendirmesi, teknolojinin kendi mantığı ile oldukça tutarlı görünmektedir. Ancak organizma ve makine arasındaki sınırı bozan ve insanı salt makineye indirgeyebilen Siborg teknolojisindeki, insan ve makine arasındaki kavramsal ayrımlar gözden geçirilmelidir (Schermer, 2009). Bu yeni teknolojinin insan zihni ve davranışı üzerinde kalıcı etkileri dolayısıyla bilişsel yetenekleri artmış, kişilikleri değişmiş, daha iyi akıl yürütebilen, yeni değer yargıları oluşturmuş, nöral implantlar üstün kapasitelerde bellek oluşturarak insanları insan-makine melezler haline getireceği bildirilmektedir (Jotterand, 2008; Reinares-Lara et al., 2018). Bu gelişmelerle ortaya çıkan yeni türdeki geliştirilmiş insanın, her açıdan sorgulamaya açık hale geldiğini belirtmek gerekir.

\section{Siborg Uygulamaları 'Sağlık Gereksinimi' Olarak Tanımlanabilir mi?}

Temel savı insanın geliştirilmemesi yönünde olan ve bunu sağlık hizmetlerinin dönüşümünü vurgulayarak bildiren bu makale, tıp etiği açısından bir değerlendirme yaparak bu savı desteklemektedir. Siborg teknolojisinin uygulama alanları dikkate alındığında, dile 


\section{Siborg ve Tıp Etiği}

getirilen etik sorunları tıp etiği bağlamında değerlendirmek üzere "Siborg bir sağlık hizmeti gereksinimi içinde tanımlanabilir mi?" sorusu yol gösterici olmaktadır. Bu bakımdan bu soru için sağlık hizmeti gereksiniminin ne olduğu, hangi hizmet ve taleplerin bu tanımın içine girdiği, bununla birlikte bir sağllk gereksinim değerlendirmesinin nasıl yapıldığının açıklanması gerekmektedir. Siborg uygulamalarının nereye kadar sağlık hizmeti olarak tanımlanabileceği ancak bu başlıklardan sonra tartışılmaya açılabilir.

\section{Sağlık Gereksinimi Nedir?}

Sağlığa ilişkin farklı tanımlar yapılmakla birlikte, en çok bilinen Dünya Sağlık Örgütü’nün “sağlık, sadece hastalık ve sakatlığın olmayışı değil, aynı zamanda fiziksel, ruhsal ve sosyal yönden tam bir iyilik hâli” tanımıdır. Sağlığa ilişkin bu tanımı hayata geçirebilmek temelde sağlık hizmeti sağlanması ile mümkündür. Sağlık Hizmetlerinin Yürütülmesi Hakkında Sağlık Bakanlığı Yönergesi'nin (2005), 4. maddesinde sağlık hizmetleri, "insan sağlığına zarar veren çeşitli etmenlerin yok edilmesi ve toplumun bu etmenlerin etkilerinden korunması, hastaların tedavi edilmesi, bedensel ve ruhsal yetenek ve becerileri azalmış olanların rehabilite edilmesi için yapılan hizmetler" biçiminde tanımlanmaktadır (Sağlık Bakanlığı, 2005).

Herkes için gerekli olanı sunması beklenen sağlık hizmeti, temelde gereksinime göre belirlenmektedir ve gereksinime göre sunulması beklenir. Çünkü gereksinim, sağlık hizmeti sunumunda öncelikleri belirlemek için kullanılan en önemli ölçüttür. John Harris, gereksinimin s1klıkla hizmetten yararlanma kapasitesiyle tanımlandığını ve yararlanma kapasitesinin artmasıyla gereksinimin artacağını belirtir. Sağlık gereksinimini sağlıkta kaynakların mikro dağılımına ilişkin olarak değerlendirmiş ve sağlık hizmeti gereksiniminin derecesini "1. Gereksinimin acilliği, yoğunluğu ya da önemi, 2. Gereksinim duyulan şeyin miktarı, 3. Bireyin gereksinim duyduğu şeyden yararlanma kapasitesi" boyutları ile belirleyici olduğunu söylemiştir. Bununla birlikte tanımladığı gereksinim örneği ile 'daha fazla miktara gereksinim duyma'nın 'daha fazla gereksinim' ile aynı olmaması gibi, ‘yararlanma kapasitesinin daha fazla olması', 'gereksinimin daha uzun süre karşılanması', 'gereksinimin acilliği, yoğunluğu ya da önemi' ya da 'gereksinim duyulan şeyin miktarı' ölçütlerinden daha iyi olmadığını belirtmektedir. $\mathrm{Bu}$ durumda "gereksinimin hangi boyutlarının sağaltım ya da var olan sağlık hizmeti kaynaklarına daha fazla işaret etmekte haklı bir gösterge oluşturduğuna karar vermek" yapılması gereken olarak belirtilir (Harris, 2004). Harris'in işaret ettiği 'gereksinim' tanımı, ister öznel bir gereksinim, ister herkes için ortak olduğuna inanılan 'nesnel' bir tanım olsun, haklı gerekçeler üzerine kurulu bir sağlık gereksinim değerlendirmesi yapılması gerektiğine işaret etmektedir.

\section{Sağlık Gereksinimi Değerlendirmesi Nasıl Yapılır?}

Sağlık gereksiniminin, sağlık hizmetlerindeki kaynakların sınırlı olması ve hükümetlerin sağlık hizmetlerine erişimi evrensel sağlayamadığı sebebiyle önemli olduğu belirtilmektedir. Bu bağlamda sağlık gereksinimi değerlendirmesi, sağlık hizmetinin toplumun sağlığını en verimli şekilde iyileştirmek için kaynakların adil kullanılmasına yönelik sistematik bir yaklaşım olarak tanımlanmaktadır (Wright et al., 1998).

Sağlık gereksinimi değerlendirmesinin yapılması, sağlık maliyetlerinin giderek artması ve her daim sağlıkta kaynakların sınırlı olması gibi temel sorunlardan dolayı çok daha önemli hale gelmektedir (Wright et al., 1998). Dolayısıyla bu değerlendirmenin yapılması, modern tıbbın geldiği noktayı da dikkate alarak özellikle hekimler için adil, etkili ve pratik çözümler sağlayabilir. Sağlık gereksinim değerlendirmesi yapılırken, sağlık hizmetlerine erişimdeki eşitsizlikleri tespit etmek, kaynakların etkin kullanımı için öncelikleri belirlemek özetle maliyet etkinliği sağlamak adına gerekli olduğu kadar hastaların bakış açılarını içeren bir denge kurmayı da sağlaması gerekir. Bu dengeyi sağlayabilmek adına Wright ve arkadaşları, doğru yapılmış bir sağlı gereksinim değerlendirmesi için sistematik bir yaklaşım önermektedirler. Bir toplumun karşılanmamış sağlık ve sağlık bakım ihtiyaçlarını belirlemek ve bu karşılanmayan ihtiyaçları karşılayabilmede değişiklikler yapabilmenin ancak sistematik bir yöntem ile sağlanabileceğini vurgularlar (Wright et al., 1998).

$\mathrm{Bu}$ yöntemin, sorunun ne olduğu, boyutu ve niteliği, mevcut hizmetlerin neleri kapsadığı, en uygun ve etkili çözümlerin neler olduğu, kaynak etkileri ve değişimi değerlendirmenin sonuçları ile başarıyı denetleme kriterlerinin neler olduğu sorularının yanıtlanması ile gerçekleştiği belirtilmektedir (Wright et al., 1998). Bu soruların yanitlanmasi ile yapilacak olan sağlık değerlendirmesinin ilk aşamasında, normatif ihtiyaçlar ile arz ve talepleri belirlemektir. Normatif ihtiyaçlar, karşılanmayacak taleplerle veya arz ile çakışabilir. Bu noktada bireysel ihtiyaçlar ile toplumun genel ihtiyaçları arasında ayrım yapmak, kaynakları etkili ve verimli bir şekilde kullanabilmek için rasyonel olarak karar vermek gerekmektedir. Sağlık hizmetlerinin, salt kişisel isteklere dayanan bir süreç olarak anlaşılmaması gerektiği, bireysel ihtiyaçlar ile toplumun genel ihtiyaçları arasında ayrım yapılarak gerçekleşmesi gerektiği vurgulanmaktadır (Wright et al., 1998). Sağlık taleplerine tepki vermek yerine sağlık gereksinim değerlendirmesi ile süreci yönetmek tıp etiği açısından da bir gereklilik olarak belirtilebilir. Çünkü bu değerlendirme, sağlık hizmetlerinin sağlanması ve kullanımında çeşitli açılardan hizmete erişim sorunlarının ele alınması için bir yöntem de sağlamaktadır (Wright et al., 1998). 


\section{F. Bulut ve G. Özkan}

\section{Siborg'un "Sağlık Gereksinimi” Boyutu}

Sağlık hizmetleri, tıbbi teknolojinin olanaklarına bağlı olarak sürekli gelişmekte ve buna bağlı olarak insanın gereksinimlerine göre şekillenebilmektedir. T1bbi teknolojinin olanaklarından biri olarak belirtebileceğimiz Siborg, tıbbı teknolojinin insanlığın hizmetine sunduğu oldukça popüler olmaya başlayan bir sağlık hizmeti olarak karşımıza çıkmaktadır.

İnsanın geliştirilmesine ahlaki açıdan karşı çıkan savların Siborg teknolojisi için de geçerli olduğu belirtilebilir. Ancak Siborg hizmeti için bu savların yeterince ikna edici olmadığını belirtmek gerekmektedir. Sağlık hizmetlerinin içinde kendini tedavi edici bir hizmet olarak sunan Siborg teknolojisinin sağladığ imkanların, birer sağlık gereksinimi olup olmadığını tartışmak gerekmektedir. Değişen dünyada, değişmekte olan insanın, ihtiyaçları da değişmektedir. Dolay1sıyla günümüz sağlık hizmetlerinin içinde ihtiyaçlar değişmekte, değişen sağlık gereksinimleri içinde de sağlık hizmetleri değişerek genişlemektedir. Bu değişimin tıp etiği açısından tartışılması sağlık hizmetlerinin geleceği açısından önemli görünmektedir. John Harris ile Wright ve arkadaşlarının önerdiği sağlık gereksinim değerlendirmesi, bu konuya yaklaşım açısından yol gösterici görünmektedir. Yanı sıra günümüz toplumundaki devam eden eşitsizlikler, sağlığa erişim sorunları ve sağlığın giderek ticarileşmesi gibi sorun başlıkları dikkate alındığında önerilen tanımların gerekli ve hala geçerliliğini koruduğu belirtilebilir.

Daha önce de belirtildiği üzere Siborg, insanı geliştirmek amacıyla insan vücuduna kalıcı olarak yerleştirilmiş veya kalıcı olarak tutturulmuş elektronik bir cihaz takılan insanı ifade etmektedir. Bu tanıma göre Siborg, insanı geliştiren bir hizmet alanı olarak karşımıza çıktığında, tıbbın amacı dikkate alınıp bir sağlık gereksinimi olamayacağı yönünde bir değerlendirme yapılabilir. Ancak Siborg teknolojileri incelendiğinde, insanı geliştiren uygulamaların yanı sıra tedavi eden bir yönünün de bulunduğunu göz ardı etmemek gerekir. Dolayısıyla sınırın nerede çizileceği veya çizilmesi gerektiği oldukça belirsiz görünmektedir. Bu belirsizlik, Siborg'un bir sağlık gereksinimi olup olmadığı tartışması ile bir yere kadar giderilebilir.

Yukarıda belirtildiği üzere bir sağlık gereksinim değerlendirmesi yapıldığında Siborg'un hangi gereksinime karşılık geldiğine yanıt vermek gerekmektedir. Buna göre Siborg'un tanımı kabul edildiğinde normatif bir ihtiyaç olamayacağı açıktır. Ancak Siborg hizmetinin bir ihtiyaçtan doğduğu belirtilebilir. Bir kolu veya bir bacağı olmayan bir kişinin, olmayan uzvun yerine kullanabileceği bir uzvun getirilmesini isteyebilir. $\mathrm{Bu}$ durum bireyin psikolojik sağlı̆̆ üzere, hayatını daha nitelikli sürdürebilme gibi durumlar açısından sağlık hizmetlerinin bir gereği olarak açıklanabilmektedir. Siborg teknolojisinde tanımlanan sorun ise hayatı daha nitelikli bir biçimde devam etmeyi sağlamasının yanı sıra organizmayı teknoloji ile uyumlu hale getirmek gibi bir vaadi bulunmaktadır. Bununla birlikte, insanın diğer insanlardan üstün niteliklere sahip, bir üst insan yaratmayı hedeflemektedir. Teknoloji ile uyumlu hale getirilen birey, örneğin daha iyi görebildiği gibi kontakt lensler sayesinde gece görüşü ile de görebilmektedir. İnsan için oldukça çekici olan bu durum, bir sağlık gereksinimi olarak değerlendirilebilir mi? Sağlık hizmetlerinin böyle bir amacı var midir?

İnsanların her türlü biyo-teknolojik gelişimi, olması gereken bir gelişim olarak algılanıp memnuniyetle karşılanması söz konusu olabilir. Diğer yandan bu gelişim, mevcut doğal düzene karşı bir tehdit olarak da algilanabilir. Bu durumda Siborg teknolojisi durdurulması ve önlenmesi gereken bir konu olarak karş1mıza çıkar. Bu iki görüş, tıbbın ve beraberinde sağlık hizmetlerinin amacını sorgulatmaktadır. Tarih boyu süregelen gelenek dikkate alındığında tıbbın amacı hiçbir zaman insanı mevcut doğal durumundan daha üst bir hale getirmek olmamıştır. Tıp, insanı daha sağlıklı kılmak, daha nitelikli bir yaşam sürdürmek için vardır. Bu süreçte 'sağlık' adına insanın mevcut durumunu da korumak zorundadır. Bu zorunluluğu tıp etiği açısından savunmakla birlikte bir sağlık gereksinim değerlendirmesi açısından da Siborg hizmetlerinde tıbbın rolünü değerlendirmek gerekir. Buna göre yapılacak olan uygulamanın terapötik mi yoksa kapasite artırıcı bir uygulama mı olup olmadığına karar verilmelidir.

Terapötik ve kapasite artırıcı ayrımının, hastalığın veya engelliliğin tedavisi için yapılan müdahaleler ile bir kişinin normal işleyişini geliştirmek veya tamamen yeni kapasitelere sahip olmak için yapılan müdahaleler arasında yapıldığ et al., 2018). Siborg teknolojisi örneğin parkinson hastalığını tedavi etmek için kullanıldığında ya da kişiye kalp pilinin takılması durumunda terapötik bir etkiye sahiptir. Ancak hafizayı artırarak yeni hesaplama teknikleri sağlayan beyin implantları doğrudan kapasite artırıcı bir uygulama olarak karşımıza çıkmaktadır. Bununla birlikte sıklıkla Siborg teknolojisinde kullanilan protez kol veya bacaklar hem terapötik hem kapasite artırıcı etkiye sahip olabilmektedir. Protez kol veya bacaklar, mevcut insan kol ve bacak özelliklerini taşıyorsa terapötik taşımıyorsa kapasite artırıcı bir uygulamadır. Terapötik olanlara karşı kapasite artırıcı uygulamaların benimsenmesi tartışmasında Siborglar bireyin bilincini, insan vücudu ile makinenin birleştirilmesiyle değiştirdiğinde etik ikilem yaratmaktadır (Park, 2014). Örneğin, atletik rekabette biyonik bir bacağa sahip koşucu insanüstü yetenekleri nedeniyle diskalifiye edilebilirken günlük etkileşimde ise aynı kişi herhangi bir kişi kadar davranışları için ahlaki olarak sorumludur (Schermer, 2009).

Siborg teknolojisi hem tedavi edici hem de kapasite artırıcı olarak da kullanılabilmektedir. Bu iki durum geliştirici hizmetler başlığında değerlendirilmektedir. 


\section{Siborg ve Tıp Etiği}

Örneğin kaza veya hastalık nedeniyle kaybedilen organ değiştirildiğinde, beyin ile bireye yerleştirilen uzvun etkileşiminin sağlanması tedavi olarak anlaşılabilir (Schermer, 2009). Bu durum, tıp etiği sınırları içerisinde kabul edilebilir görünmektedir. Ancak diğer yandan bu aşamada geliştirici sağlık hizmetlerinin sağlık hizmeti kapsamı içine girip girmediği sorunu ortaya çıkmaktadır. Bu sorun, toplum sağlığı ihtiyaçlar1 ve kişisel ihtiyaçlar bağlamında değerlendirilebilir.

Toplum sağlığı ihtiyaçlarını kişisel ihtiyaçlarla bütünleştirmek, sağlık hizmeti sunumunu gerçekleştirmek amacına yardımcı olabilir. Kişinin sağllk hizmetlerinden faydalanma durumu toplumun sağlık hizmetlerinden faydalanma kapasitesini daraltıyorsa bu aşamada sağlanan hizmet kapsamını sınırlandırmak yararlı olabilir. Siborg teknolojisi kişiye özel bir sağl1k hizmeti alanı sunmaktadır. Ancak bu alan, kişinin kapasite artırmaya yönelik salt isteklerinden oluşan sınırsız bir alan olmamalıdır. Bu nedenle taleplerin bir sağlık gereksinimi olup olmadığının değerlendirmesini iyi yapmak gerekir. İnsanın görme yetisini geri kazanması ile gece görüşü kazanması arasında sağlık gereksinimi açısından fark vardır. Kapasite artırmaya yönelik talepler, bireylerin gerçek amaçları açısından daima risk taşır. Bireyin hangi amaç için kapasitesini artırmak istediği, bu durumu nasıl kullanacağını kestirmek oldukça güç olacaktır. Bu nedenle, genel olarak sağlık gereksinimi, sağlık hizmetleri içerisinde tedavi olmak gibi toplumun ortak nesnel ihtiyaçları ile birlikte değerlendirilebilir.

Son olarak tıp etiği açısından yapılan değerlenmede, Siborg'un bir sağlık gereksinimi olmadığı Harris'in gereksinim tanımından hareketle ortaya konmuştur. Siborg teknolojisinin, modern tıbbın içinde giderek talep yaratan bir durum olarak karşımıza çıkacağı öngörülebilir. Sağlık hizmetlerinin bireylerin salt amaçlarına indirgenemeyeceği, bu durumun toplum sağlığı başta olmak üzere bireyin varoluşu açısından da riskler taşıyacağı söylenebilir. İnsan olmanın taş1dığı anlam, insan vücudunun parçalarında aranması, gelecekte bir varoluş krizine yol açabileceği gibi sağlık hizmetlerinin var oluş amacını da dönüşüme uğratabilecek bir potansiyele sahiptir. Bu ve benzeri kayg1larla Siborg teknoloji uygulamalarının sağlık hizmetlerinde yer alması sınırlandırılmalı, ilgili düzenlemeler oluşturularak organizmanın kapasitesinin artırılmasına yönelik uygulamalar yasaklanmalıdır.

\section{Sonuç}

Sonuç olarak sağlık hizmetlerinin içinde yer almaya başlayan Siborg teknolojisi, sağlık hizmetlerini dönüşüme uğratan bir sorun alanı olarak tanımlanabilir.

İnsanın geliştirilmesine yönelik uygulamalar açısından Siborg teknolojisine 1lımlı bir yaklaşım sergilenmektedir. $\mathrm{Bu}$ teknoloji ile insan tedavi edilebilir olma pozisyonundan tamir edilebilir bir pozisyona geçmekte, sağlık hizmetleri de bu pozisyona ortak olmaktadır. $\mathrm{Bu}$ bağlamda sağlık hizmetinin koruyucu, tedavi edici, rehabilite edici etkinliklerine yeni bir boyut eklenmiştir: Organizmayı teknoloji ile uyumlu hale getirici.

Modern tıbbın teknoloji ile bu denli yakınlığı sorgulanmalıdır. Tıbbi teknolojinin bütün imkanlarını hastalıkları önlemek, tedavi etmek, rehabilite etmek gibi hizmetlerde sağlıkta eşitsizliklerin önünü açmadan kullanmak gerekmektedir. Bu bağlamda Siborg teknolojisi, bireyin salt kişisel isteklerinden oluştuğu için eşitsizliğin önünü kolaylıkla açabilen bir hizmet alanıdir.

Siborg hizmetlerinin bir gereksinim olup olmadiğ konusunda yapılan sağlık gereksinim değerlendirmesinde, gereksinim olmadığı buna karşın talep yaratan bir teknoloji alanı olduğu sonucuna ulaşılmıştır. Siborg teknolojisi hem tedavi edici hem de kapasite artırıcı bir uygulama alanı yaratmaktadır. Bu bağlamda tıp etiği, Siborg teknolojisinin kapasite artırıcı uygulamalarına karşı çıkmalı, iyi bir sağlık gereksinimi değerlendirmesi yapılması gerektiğini savunmalıdır. Ayrica yasal düzenlemelerde Siborg teknolojisine yer verilmeli, sınırları belirlenmelidir: Talepler, karşılanamayacak düzeyde yeni talepler yaratacağından olası riskleri göz önünde bulundurulmalıdır.

\section{Teşekkür}

Katk1 ve özenli değerlendirmelerinden dolayı Prof. Dr. M. Murat Civaner'e teşekkür ederiz.

Etik Kurul Bilgisi:

Derleme türünde makale olması nedeniyle Etik Kurul onayı gerektirmemektedir.

\section{Kaynaklar}

1. Barfield W, Williams A. Law, Cyborgs, and Technologically Enhanced Brains. Philosophies, 2017;2:6

2. Bulut F, Civaner MM. Modern tıp insancıl özünü yitiriyor: Artık "Hasta yok, Hastalık var!". Turkish Journal of Bioethics, 2016;3:66-73

3. CYBORG ARTS. (2020). CYBORG ARTS. Retrieved March 1, 2020, from https:/www.cyborgarts.com/

4. Dülger MV. Yapay Zekalı Varlıkların Hukuk Dünyasına Yansıması: Bu Varlıkların Hukuki Statüleri Nasıl Belirlenmeli? Terazi Hukuk Dergisi, 2018:13;82-87.

5. Gillett G. Cyborgs and moral identity. Journal of Medical Ethics, 2006:32;79-83.

6. Hansson SO. Implant ethics. Journal of Medical Ethics, 2005:31;519-525.

7. Haraway DJ. Siborg Manifestosu, çev. Akınhay, O.,1rd edition, Agora kitaplığı, İstanbul, 2006.

8. Harris J. Mikro Dağılım: Hastalar arasında seçim yapma. çev. Civaner MM. Toplum ve Hekim, 2004:19;2 


\section{F. Bulut ve G. Özkan}

9. Jotterand F. Beyond therapy and enhancement: The alteration of human nature. NanoEthics, 2008:2;15-23.

10. Leonhard G. Teknolojiye Karşı İnsanlık, çev. Akkartal, İ; Akkartal, C., 1rd edition, Siyah Kitap, İstanbul, 2018.

11. Miah A. Ethics Issues Raised by Human Enhancement. Retrieved March 2, 2020, 2012: from OpenMind website: https://www.bbvaopenmind.com/wpcontent/uploads/2012/02/BBVA-OpenMind-Ethics-IssuesRaised-by-Human-Enhancement-Andy-Miah.pdf.

12. Miles SH, Siegler M, Schiedermayer DL, Lantos JD \& La Puma J. The total artificial heart: An ethics perspective on current clinical research and deployment. Chest, 1988:94;409413.

13. Park E. Ethical Issues in Cyborg Technology: Diversity and Inclusion. NanoEthics, 2014:8;303-306.

14. Reinares-Lara E, Olarte-Pascual C, Pelegrín-Borondo J. Do you want to be a cyborg? The moderating effect of ethics on neural implant acceptance. Computers in Human Behavior, 2018:85;43-53.

15. Schermer M. The mind and the machine. On the conceptual and moral implications of brain-machine interaction. NanoEthics, 2009:3;217-230.
16. Sağlık Bakanlığı. Sağlık Hizmetlerinin Yürütülmesi Hakkında Sağlık Bakanlığı Yönergesi, 2005:Retrieved from https://www.ttb.org.tr/mevzuat/index.php?option=com_content $\& \mathrm{id}=240$

17. The Guardian. Neil Harbisson: the world's first cyborg artist. 2014: Retrieved from https://www.theguardian.com/artanddesign/2014/may/06/neilharbisson-worlds-first-cyborg-artist

18. van Hooijdonk R. 10 technologies that could one day turn us all into real cyborgs. Retrieved March 1, 2020, 2017:from https://www.richardvanhooijdonk.com/blog/en/10 -

19. technologies-that-could-one-day-turn-us-all-into-real-cyborgs

20. Warwick K. Cyborg morals, cyborg values, cyborg ethics. Ethics and Information Technology. 2003:5;131-137

21. Wright J, Williams R, Wilkinson JR. Health needs assessment. Development and importance of health needs assessment. British Medical Journal, 1998:316;1310-1313.

22. Nişanyan Sözlük, https://www.nisanyansozluk.com/?k=sibernetik\&lnk=1, Erișim Tarihi: 20.02 .2020 